\title{
PELATIHAN PEMBUATAN SARI KEDELAI REMPAH UNTUK PENINGKATAN DAYA TAHAN TUBUH DALAM MENGHADAPI PANDEMI Covid-19
}

\author{
Oleh: \\ Prima Retno Wikandari', Lenny Yuanita ${ }^{1}$, Sari Edi Cahyaningrum ${ }^{1}$, Nuniek Herdyastuti ${ }^{1}$, \\ Amaria $^{1}$ \\ ${ }^{1} J u r u s a n$ Kimia Universitas Negeri Surabaya \\ 1primaretno@unesa.ac.id
}

\begin{abstract}
Abstrak
Coronavirus disease-19 (Covid-19) adalah penyakit yang memberikan resiko kematian yang sangat tinggi. Alternatif pencegahan adalah dengan konsumsi susu kedelai berempah karena dapat meningkatkan imun dan kaya antioksidan. Kegiatan ini bertujuan untuk (1) memberikan pengetahuan tentang Covid-19 dan cara penanggulangannya, (2) memberikan keterampilan pembuatan sari kedelai berempah, dan (3) melakukan sosialisasi produk kepada masyarakat oleh peserta latih. Metode pelatihan dilakukan secara daring dan diunggah melalui youtube https://youtu.be/mb 6H2biczA, dilanjutkan praktek mandiri dan sosialisasi produk hasil praktek mandiri kepada masyarakat sekitar. Hasil kegiatan menunjukkan peserta latih memberikan respon bahwa materi pengetahuan tentang Covid-19 dan cara pembuatan sari kedelai adalah penting dan cara penyajiannya sangat menarik. Sebanyak $86.7 \%$ peserta menyatakan bahwa materi adalah baru, dan $60 \%$ peserta menjawab akan mempraktekkan hasil pelatihan. Satu orang peserta telah mampu menginisiasi tetangganya untuk berwirausaha dan telah menerima pesanan. Sebanyak $86.7 \%$ peserta latih telah melakukan sosialisasi kepada keluarga $(46.7 \%)$, tetangga $(33.3 \%)$ dan teman kantor $(13.3 \%)$. Tanggapan peserta sosialisasi terhadap produk sari kedelai rempah menyatakan suka $(46.7 \%)$ sampai sangat suka $(53.3 \%)$, Respon peserta sosialisasi menyatakan bahwa mereka menyatakan kegiatan ini cukup manfaat $(33.3 \%)$ hingga sangat manfaat $(66.7 \%)$ dan $100 \%$ berkeinginan untuk mengetahui pembuatan sari kedelai rempah.
\end{abstract}

Kata Kunci: Covid-19, imunitas, sari kedelai berempah, pelatihan

\begin{abstract}
Coronavirus disease-19 (Covid-19) provide a high risk of death. An alternative to prevent is consumption of spiced soybean juice that will increase the immunity and has a high antioxidant. This activity aims to (1) provide knowledge about Covid-19 and how to overcome it, (2) provide skills in making spiced soybean juice, and (3) disseminate products to the community by trainees. The training method is carried out online and uploaded via youtube https://youtu.be/mb_6H2biczA, followed by independent practice and socialization of products to the surrounding community. The results showed that the material is important and the way of serving it is very interesting. As many as $86.7 \%$ of participants stated that the material was new, and $60 \%$ of participants would practice of making spicy soybean juice. As many as $86.7 \%$ of trainees had conducted outreach to their families (46.7\%), neighbors (33.3\%) and work colleagues (13.3\%). One participant has been able to initiate a neighbor into entrepreneurship and has received orders. The response of the socialization participants stated that they like the product $(46.7 \%)$ to very like it (53.3\%), and stated that this activity was quite beneficial (33.3\%) to very beneficial (66.7\%) and expressed to know the process of making spice soy juice.
\end{abstract}

Keywords: Covid-19, immunity, spiced soy juice, trained

\section{PENDAHULUAN}

COVID-19 adalah adalah suatu penyakit yang disebabkan oleh virus coronavirus 2
(SARS-CoV-2). Pada umumnya virus ini tersebar penularannya melalui pernafasan atau adanya interaksi melalui droplet seseorang yang telah terinveksi virus tersebut antara dua hingga 14 hari. Mencuci tangan 
dengan sabun, minum vitamin $\mathrm{C}$ dan $\mathrm{E}$, memakai masker, menjaga jarak dengan orang lain, adalah langkah-langkah minimal yang harus dilakukan agar seseorang terhindar dari virus Covid-19 (Singhal, 2020). Namun hal lain yang lebih penting lagi dalam pencegahan dan penularan virus Covid-19 adalah pertahanan tubuh dimana hal ini hanya dapat ditingkatkan jika seseorang mempunyai tingkat imunitas yang sangat tinggi.

Mikroorganisme pathogen maupun virus dianggap sebagai benda asing oleh tubuh kita, yang akan menstimulasi tubuh untuk mengeluarkan immunoglobulin (lgG, IgA dan $\lg$ M) suatu senyawa yang bertanggung jawab terhadap sistem imun. Stress oksidatif adalah penyumbang terbesar terjadinya tingkat kematian yang disebabkan oleh adanya disregulasi imun dan menjadi penyebab beberapa penyakit lainnya, dan sistim imun sendiri sangat sensitive terhadap stress oksidatif. Oleh sebab itu konsumsi vitamin dan antioksidan menjadi sangat penting dalam menjaga sistem imun (Hajjian, 2015).

Terkait dengan peningkatan imunitas, senyawa genestein pada sari kedelai merupakan immonostimulan terhadap produksi immonoglobolin IgA dan IgG. Hasil uji coba pada mencit, pemberian sari kedelai mampu meningkatkan kadar IgA dan IgG. (Levinson dan Jawetz, 2003). Isoflavon aglikon genestein juga diketahui mempunyai aktivitas antioksidan untuk menangkal Reactive Oxygen Species adala Reaktif Oxygen Species (ROS) yang berlebih, agar melindungi jaringan dari kerusakan lebih lanjut dan memicu terjadinya penyakit autoimun (Askanase, et al, 2020).

Senyawa gingerol, shogaol yang memberikan rasa pedas pada jahe adalah senyawa antioksidan. Senyawa ini dapat meningkatkan plorifirasi sel limfosit B dalam merespon adanya antigen. Peningkatan sel limfosit B menunjukkan adanya peningkatan respon imun humoral dalam tubuh (Tejasari et al, 2002). Kayu manis mengandung kadar trans-sinamaldehid yang menjadi sumber senyawa antioksidan. Kayu manis manis mempunyai aktivitas antioksidan yang sangat kuat dengan IC50 9.431 ppm (Mutiara et al., 2015). Ekstrak kayu manis diketahui mampu memperbaiki jaringan hepar tikus yang terpapar ROS dan menurunkan kadar SGOT dan SGPT (Rafita, 2015)

Pengetahuan terhadap cara antisipasi dalam mencegah penularan dan penanganan terhadap yang sudah terdampak Covid-19 tentunya sangat diperlukan oleh masyarakat. Salah satu antisipasi yang bisa ditawarkan adalah dengan konsumsi sari kedelai berempah. Cara antisipasi ini nampaknya adalah cara yang sangat "bersahabat", karena sari kedelai berempah adalah minuman kesehatan dan bukan obat, sehingga diharapkan akan lebih mudah untuk dapat diterima oleh masyarakat. Paduan rasa sari kedelai dan rempah yang gurih dan memberikan rasa hangat akan dapat meningkatkan daya terima sari kedelai. Selain rasa yang enak, jenis minuman ini berdampak positif untuk meningkatkan sistem imun dan penanggulangan bahaya radikal bebas.

Pengabdian Kepada Masyarakat ini dikemas dalam bentuk Pelatihan yang bertujuan untuk (1) memberikan pengetahuan tentang Covid-19 dan cara penanggulangannya, (2) memberikan keterampilan pembuatan sari kedelai rempah, dan (3) melakukan sosialisasi produk kepada masyarakat oleh peserta latih.

\section{METODE}

\section{Bentuk dan Tahap Kegiatan}

Sesuai dengan kebutuhan di masyarakat maka bentuk kegiatan ini adalah pelatihan dalam bentuk penyuluhan dan pemberian keterampilan. Kegiatan dilanjutkan dengan diseminasi hasil pelatihan ke masyarakat oleh peserta latih. Tahap kegiatan yang dilakukan adalah sebagai berikut $\because$ (1) koordinasi kegiatan dengan Ketua Dharma Wanita FMIPA Universitas Negeri Surabaya, (2) persiapan alat dan bahan, (3) pembuatan video tutorial proses pembuatan sari kedelai rempah, (3) pelaksanaan pelatihan secara daring melaui tayangan PPT materi penyuluhan dan pemutaran video tutorial pembuatan sari kedelai rempah, (4) praktek mandiri peserta latih dengan pendampingan melalui komunikasi dalam WA group (5) unjuk kerja hasil praktek mandiri melalui WA group (6) sosialisasi produk hasil pelatihan ke masyarakat dengan bukti foto kegiatan dan mendapatkan data respon tingkat kesukaan terhadap produk yang dihasilkan.

Pelaksana kegiatan adalah tim Pengabdian Kepada Masyarakat Jurusan Kimia Universitas Negeri Surabaya sebanyak 5 orang. Sasaran pelatihan adalah ibu-ibu Dharma Wanita FMIPA Universitas Negeri Surabaya dan melibatkan masyarakat di sekitar tempat tinggal peserta latih sebagai sarana untuk sosialisasi produk pelatihan. 


\section{Materi Pelatihan dan Pandampingan}

Materi pelatihan berupa: (1) penyuluhan tentang manfaat sari kedelai rempah untuk peningkatan imun dalam menghadapi pandemi Covid-19. Materi diberikan dalam bentuk tayangan power point dan (2) tutorial proses pembuatan sari kedelai rempah meliputi pemilihan bahan, resep baku sari kedelai rempah, tahap pembuatan sari kedelai rempah dan cara sterilasi wadah kemasan.

Pendampingan dalam proses kerja mandiri dalam pembuatan sari kedelai rempah dilakukan melalui WA group sebagai sarana motivasi, diskusi dan unjuk produk hasil kerja mandiri. Pendampingan juga dillakukan saat sosialisasi dalam hal pelaksanaan sosialisasi dan pengambilan data respon masyarakat terhadap produk sari kedelai rempah.

\section{Evaluasi Pelaksanaan Kegiatan}

Evaluasi pelaksanaan kegiatan dijaring melalui angket penilaian terhadap pelaksanaan kegiatan. Peserta latih memberikan penilaian dalam bentuk scoring 1-4 yang menunjukkan dari tidak suka sampai dengan sangat suka. Pengumpulan data dilakukan melalui goglee form dan diolah secara deskriptif kuantitatif.

Evaluasi keterampilan dan kreativitas peserta latih dijaring melalui angket penilaian dari masyarakat yang dilibatkan dalam sosialisasi melalui google form.

\section{HASIL DAN PEMBAHASAN}

Kegiatan Pengabdian Kepada Masyarakat (PKM) ini dilaksanakan dalam bentuk pelatihan yang dilaksanakan secara daring. Tim PKM terdiri dari 5 (lima) orang dan diikuti oleh 20 (dua puluh) orang peserta dari ibu-ibu Dharma Wanita FMIPA Universitas Negeri Surabaya. Kegiatan berjalan dengan lancar, peserta pelatihan mengambil peran aktif dalam hal bertanya, praktek mandiri, berkreasi, hingga melakukan sosialisasi ke masyarakat sekitar tempat tinggal peserta latih.

Proses pelatihan dalam pemberian keterampilan pembuatan sari kedelai rempah telah berhasil dengan indicator keberhasilan karakteristik produk yang dihasilkan telah memenuhi kriteria yang diinginkan dan respon tingkat kesukaaan yang tinggi dari masyarakat.

Tahap Persiapan Termasuk dalam tahap ini adalah tahap koordinasi dengan kelompok sasaran pelatihan, persiapan alat dan bahan, pembuatan video tutorial pembuatan sari kedelai rempah, pembuatan resep cara pembuatan kedelai rempah, penyiapan materi penyuluhan dan persiapan angket respon peserta latih dan tingkat kesukaan produk untuk mendapatkan data bahan evaluasi kegiatan.

Koordinasi dilakukan dengan menghubungi Ketua Dharma Wanita FMIPA Unesa untuk mendapatkan persetujuan kegiatan, peserta dan pembuatan WA group Susu Kedelai Rempah untuk memudahkan koordinasi tim PKM dengan peserta pelatihan, serta penentuan jadwal kegiatan.

Persiapan bahan dan alat dilakukan untuk keperluan pembuatan video tutorial dan persiapan paket pelatihan untuk kerja mandiri peserta latih yang berisi kedelai, jahe dan kayu manis, botol kemasan dan kain penyaring.

Pembuatan video tutorial dilakukan untuk memudahan peserta latih melakukan kerja mandiri. Isi video meliputi antara lain: (1) cara pemilihan kedelai sebagai bahan dasar, (2) perbandingan komposisi air dan kedelai untuk membuat sari kedelai dengan konsistensi yang disukai konsumen, (3) penjelasan tentang maksud setiap tahap yang dilakukan, (4) penjelasan tentang hieginisme dan keamanan pangan.

Komponen isi angket disusun untuk mengetahui respon peserta latih terkait peaksanaan kegiatan dan angket penilaian tingkat kesukaan produk hasil praktek mandiri peserta latih oleh masyarakat untuk mengetahui keberhasilan pembuatan produk.

Tahap pelaksanaan pelatihan Tahap pelaksanaan PKM dilakukan pada tanggal 29 Agustus 2020 diikuti oleh 20 peserta melalui platform daring (Gambar 1).

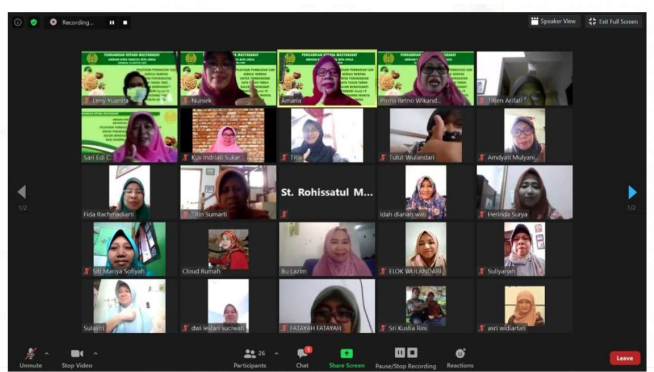

Gambar 1. Peserta PKM Sari Kedelai Rempah melalui zoom meeting (Tim PKM Kimia FMIPA dengan back drop warna hijau) 
Acara dibuka oleh Ibu Ketua Dharma Wanita FMIPA Unesa dengan acara inti yaitu (1) pemaparan materi pengetahuan tentang Covid-19, (2) tutorial pembuatan sari kedelai rempah melalui pemutaran vidio pembuatan sari kedelai rempah (3) Sesi tanya jawab, (4) Penyampaian jadwal tindak lanjut Penutup.

Pemaparan materi dengan judul "Manfaat Sari Kedelai Rempah Pada Peningkatan Daya Tahan Tubuh Dalam Menghadapi Pandemi Covid-19 dilakukan secara daring. Penjelasan materi meliputi pengertian tentang virus, proses virus SARS-CoV dalam menyerang pernafasan, cara penularan, cara pencegahan, kasus penyebaran Covid-19, serta bagaimana peran sari kedelai berempah yang kaya antioksidan dapat membantu mengantisipasi dampak Covid-19.

Pelatihan untuk pembuatan susu kedelai rempah dilakukan dengan pemutaran video yang telah disiapkan sebelumnya. Agar peserta dapat mengikuti dengan baik, maka video tutorial ini juga diunggah melalui youtube https://youtu.be/mb 6H2biczA. Unggah pada media ini juga dimaksudkan sebagai luaran pelatihan ini, sehingga dapat dimanfaatkan oleh masyarakat luas. Sehari sebelum pelatihan yaitu pada tanggal 28 Agustus 2020, video ini telah diunggah dan dilihat sebanyak 60 kali dan bertambah 36 kali dilihat pada satu bulan berikutnya.

Pada akhir acara dilakukan sesi tanya jawab yang dilakukan melalui media chating dan pertanyaan secara langsung, serta diinformasikan langkah tindak lanjut yaitu adanya praktek mandiri dan sosialisasi produk.

Praktek Mandiri Praktek mandiri dimaksudkan agar para peserta latih dapat berlatih sendiri dan terampil untuk membuat sari kedelai berempah. Bahan dan peralatan penunjang diberikan oleh tim PKM dalam satu paket untuk setiap peserta latih (Gambar 2)

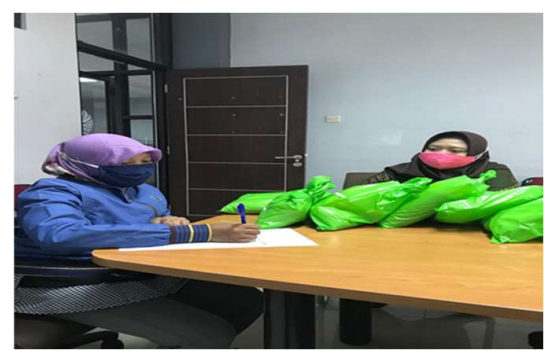

Gambar 2. Penyerahan paket pelatihan untuk praktek mandiri.
Praktek mandiri ini diwajibkan kepada para peserta latih sebagai tindak lanjut kegiatan PKM. Hasil praktek mandiri dilaporkan kepada tim melalui media WA group seperti terangkum pada Gambar 3.

Hasil wawancara untuk produk yang dihasilkan menunjukkan bahwa produk yang dihasilkan telah memenuhi karakteristik produk sari kedelai rempah yang dihasilkan terutama dalam hal konsistensi, warna dan aroma produk yaitu cairan agak kental dengan warna putih kecoklatan, dan beraroma rempah jahe, kayu manis dan sereh dengan rasa gurih, rasa jahe yang sedikit pedas.
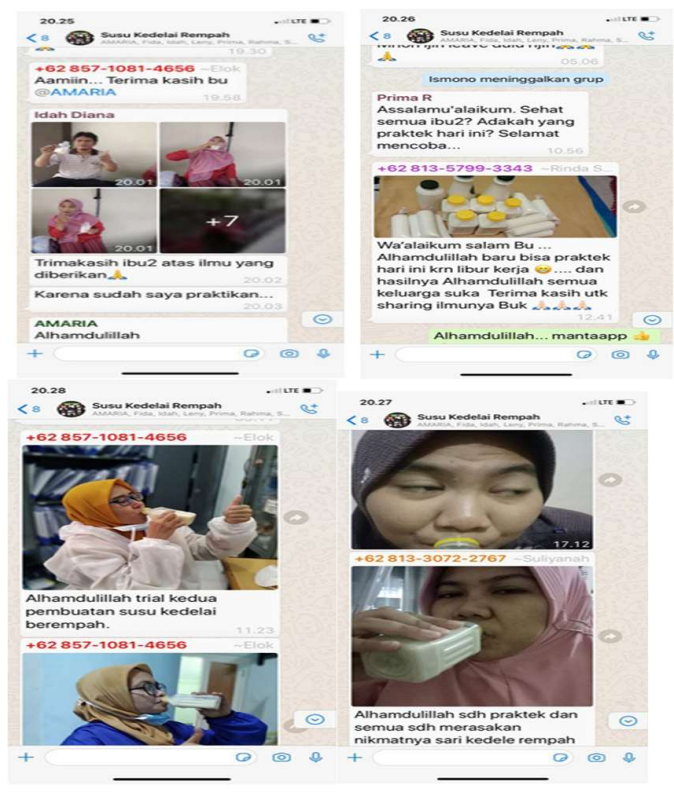

Gambar 3. Koordinasi melalui WA group pada saat praktek mandiri.

Walaupun tanpa ditugaskan, peserta latih dengan motivasinya sendiri berupaya menampilkan kreativitasnya dalam gelar produknya seperti ditampilkan pada Gambar

4.

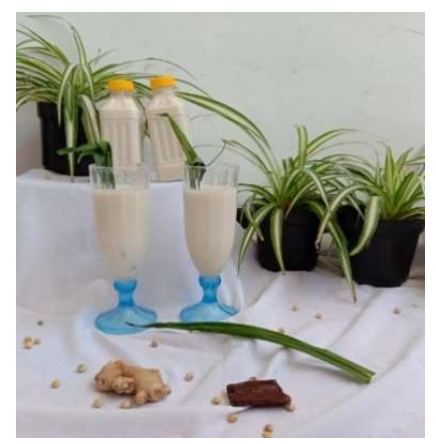


Gambar 4. Gelar produk sari kedelai rempah hasil praktek mandiri

Tahap sosialisasi Tahap sosialisasi produk hasil praktek mandiri selanjutnya disosialisasikan ke masyarakat sekitar. Tahap ini dimaksudkan sebagai langkah diseminasi pengetahuan dan sosialisasi produk, serta untuk menilai keberhasilan pembuatan sari kedelai rempah oleh peserta latih.

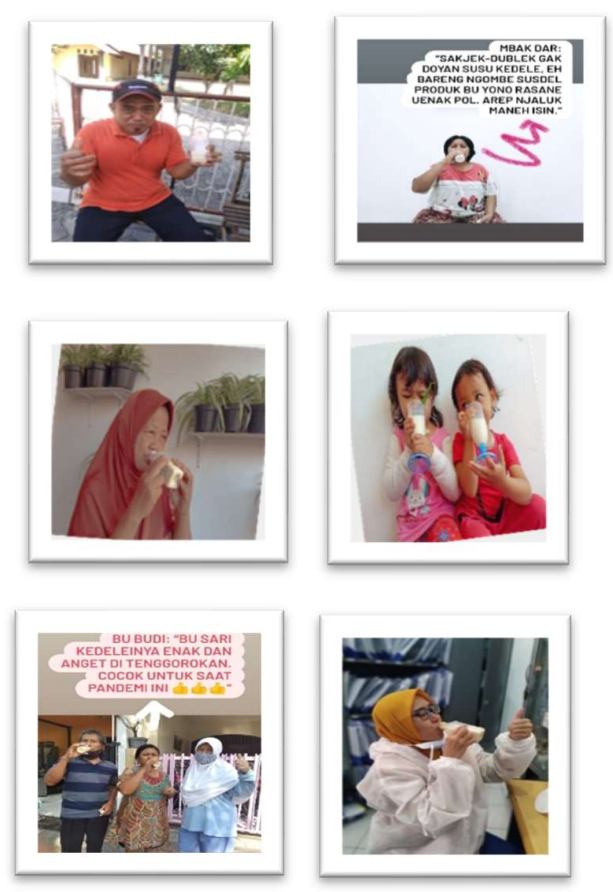

Gambar 5. Sosialisasi produk hasil praktek mandiri

Sosialisasi produk sari kedelai rempah dilakukan oleh peserta latih kepada warga sekitar tempat tinggal masing-masing. Peserta latih diminta untuk mengirimkan laporan bukti foto sosialisasi. Sari kedelai rempah dibagikan baik kepada anak-anak, hingga orang dewasa, serta orang tua baik laki-laki maupun perempuan. Antusiasme dalam sosialisasi nampak dari beberapa dokumen foto yang dikirimkan ibu-ibu (Gambar 5).

Tahap Evaluasi Evaluasi hasil kegiatan dilakukan cara mengisikan angket respon peserta latih melalui goglee form. Angket diisi oleh 15 responden yang berasal dari peserta latih. Respon yang dijaring antara lain meliputi pentingnya dan kebaruan materi pelatihan, pelaksanaan pelatihan, keinginan peserta latih untuk praktek mandiri/berwirausaha dan sosialisasi ke masyarakat.

Hasil evaluasi menunjukkan bahwa sebanyak $86.7 \%$ peserta menyatakan bahwa materi adalah baru. Data tersebut menunjukkan bahwa materi yang disampaikan menyajikan pengetahuanpengetahuan baru khususnya pengetahuan tentang Covid-19 itu sendiri dan mekanismenya dalam menyerang pernafasan, manfaat sari kedelai berempah yang kaya antioksidan dalam menangkal Covid-19, serta proses pembuatan sari kedelai rempah. Respon peserta latih terhadap pelaksanaan pelatihan menunjukkan bahwa $60 \%$ peserta menyatakan sangat menarik, dan $40 \%$ menyatakan menarik. Sebanyak $60 \%$ peserta menjawab akan mempraktekkan hasil pelatihan. Satu orang peserta bahkan telah mampu menginisiasi tetangganya untuk berwirausaha dan telah menerima pesanan. Sebanyak $86.7 \%$ peserta latih telah melakukan sosialisasi kepada keluarga $(46.7 \%)$, tetangga (33.3\%) dan teman kantor (13.3\%).

Evaluasi terhadap keberhasilan proses pelatihan pembuatan sari kedelai rempah ditunjukkan dari respon hasil sosialisasi produk yang dibuat oleh peserta latih. Sebanyak $46.7 \%$ peserta sosialisasi menyatakan suka sampai sangat suka (53.3\%). Respon peserta sosialisasi juga menyatakan bahwa mereka menyatakan kegiatan ini cukup manfaat (33.3\%) hingga sangat manfaat $(66.7 \%)$ karena peserta latih juga telah mensosialisasikan manfaat sari kedelai rempah terutama untuk meningkatkan imun dalam mengantisipasi Covid-19.

Peserta sosialisasi juga berkeinginan untuk mengetahui proses pembuatan sari kedelai rempah, bahkan ada satu peserta latih (Ibu Suliyanah) telah berhasil menularkan ilmu dan keterampilannya kepada tetangganya yang dibuktikan dengan telah dikembangkannya produk ini menjadi satu usaha mandiri dan telah laku dijual

(Gambar 6)
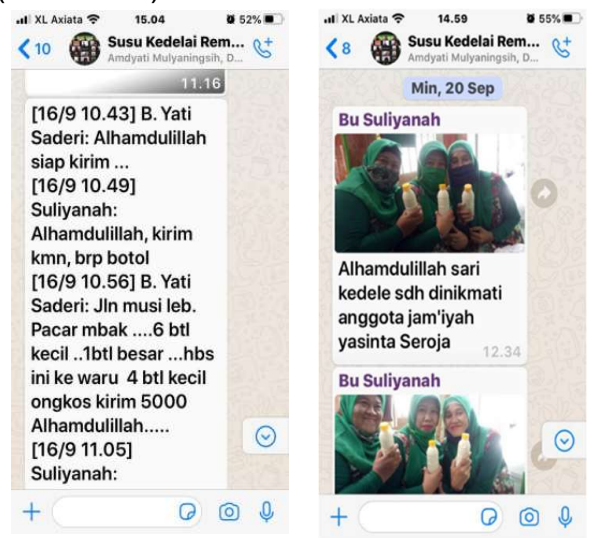
Gambar 6. Bukti wirausaha hasil PKM

\section{SIMPULAN DAN SARAN}

\section{Simpulan}

Kegiatan PKM ini telah memenuhi kebutuhan masyarakat tentang Covid-19, khususnya pengetahuan tentang virus, mekanisme menginfeksi sistem pernafasan, serta alternatif cara penanggulangan melalui peningkatan imun dengan konsumsi sari kedelai rempah. Telah dilakukan pelatihan tentang cara pembuatannya dan hasil praktek mandiri telah menunjukkan peserta latih mampu menghasilkan produk dengan karakteristik sari kedelai rempah yang diinginkan. Hasil sosialisasi produk hasil praktek mandiri menunjukkan bahwa produk dapat diterima masyarakat dengan kriteria suka sampai sangat suka.

Hasil evaluasi kegiatan menunjukkan bahwa kegiatan ini mampu meningkatkan pengetahuan masyarakat, mampu memotivasi peserta dalam meningkatkan keterampilan dan kreativitasnya serta mampu memberdayakan masyarakat.

Luaran dari kegiatan PKM ini adalah video cara pembuatan sari kedelai rempah yang telah diunggah melalui media you tube, dan produk sari kedelai rempah, Dampak lain dari kegiatan ini adalah munculnya satu wirausaha baru yang perlu terus dibina dan dikembangkan melalui kegiatan PKM yang berkelanjutan.

\section{Saran}

Rekomendasi dari kegiatan PKM ini adalah melaksanakan tindak lanjut terhadap hasil pelatihan khususnya dalam pembentukan kelompok bisnis dari cikal bakal usaha yang sudah terbentuk dan melakukan pembinaan antara lain melakukan pelatihan keterampilan kewirausahaan, membantu dalam menciptakan merk, desain kemasan dan cara pengemasan yang hieginis serta mengupayakan perijinan Pangan Industri
Rumah Tangga (PIRT) sebagai legal formal dalam melakukan usaha. Tindak lanjut lain yang dapat dilakukan adalah menciptakan Teknologi Tepat Guna guna meningkatkan produksi dalam skala yang lebih besar serta menjamin hiegienitas dalam proses pengemasan

\section{DAFTAR PUSTAKA}

Askanase AD, Khalili L, Buyon JP. 2020. Thought on Covid-19 and autoimmune disease. Letter. Lupus Sci Med. 2020;7(1):e000396. doi:10.1136/lupus2020-000396

Hajjian, Shabnam, 2015. Positive efect of antioxidants on immune system. Immunopathol Persa. 1(1):e02

Levinson, W., Jawet, E. 2003. Human immunodeficiency virus. In Medical Microbiology and Immonology. Seven ed. International Edition. Singapore pp 28694.

Mutiara R., Sani, E.P., Dina, M., 2015. Uji Altivitas Antioksidan Ekstrak Kulit Kayu Manis (Cinnammon burmannii Ness exBI ) dan Formulasinya Dalam Bentuk Sediaan Masker Gel Peel Off. Prosiding Penelitian SPeSIA, Unisba, pp 602-606

Singhal Tanu. 2020. A Review of Coronavirus Disease-2019 (COVID-19).

The Indian Journal of Pediatrics 87(4):281-286

https://doi.org/10.1007/s12098-02003263-6

Rafita, Ita Dwi, 2015. Pengaruh ekstrak kayu manis (Cinnamomum burmanii) terhadap gambaran hispatologi dan kadar SGOT SGPT hepar tikus yang diinduksi parasetamol, Skripsi, Jurusan Biologi, FMIPA, Universitas Negeri Semarang.

Tejasari, Fransiska, R.Z., Dondin S., 2011.Aktivitas stimulasi komponen bioaktif rimpang jahe (Zingiber offcinale Roscoe) pada sel limfosit B manusia secara in vitro . Jurnal Teknol dan Industri Pangan, 13 (1) : 47-53 